\title{
PENGETAHUAN DAN SIKAP MASYARAKAT TERHADAP PENGGUNAAN STYROFOAM SEBAGAI WADAH MAKANAN
}

\author{
Meutia Maulida Setiawan ${ }^{1}$, Suparni $^{2}$, Tri Nurhayati ${ }^{3}$ \\ ${ }^{1,2}$ Program Studi Sarjana Kesehatan Masyarakat, STIKes Dharma Husada, Bandung, Indonesia \\ Email : mutiaa564@gmail.com
}

\begin{abstract}
Abstrak
Styrofoam adalah material dari polytrene kemasan yang umumnya berwarna putih dan kaku yang sering digunakan sebagai kotak pembungkus makanan. Styrofoam dijadikan wadah makanan karena murah, mudah didapat, tidak mudah rusak, tidak perlu dibersihkan, dan dapat langsung dibuang ketika sudah tidak digunakan. Akan tetapi Styrofoam berbahaya bagi kesehatan dan lingkungan. Tujuan penulisan literatur review ini untuk mengetahui hubungan pengetahuan dan sikap masyarakat terhadap penggunaan Styrofoam sebagai wadah makanan. Metode yang digunakan adalah literatur review dengan mencari sumber informasi melalui database secara online didapatkan sebanyak 271 jurnal dari tiga database kemudian di screening sehingga didapatkan 9 artikel jurnal yang terdiri dari jurnal nasional dan jurnal internasional yang dapat dianalisis sesuai dengan topik yang diangkat. Berdasarkan hasil literatur didapatkan bahwa pengetahuan dan sikap masyarakat berhubungan dengan penggunaan Styrofoam sebagai wadah makanan.
\end{abstract}

Kata Kunci :Pengetahuan, Sikap, Styrofoam, wadah makanan

\section{PENDAHULUAN}

Styrofoam adalah material dari polytrene kemasan yang umumnya berwarna putih dan kaku yang sering digunakan sebagai kotak pembungkus makanan. Tadinya bahan ini dipakai untuk pengaman barang non-makanan seperti barang-barang elektronik agar tahan benturan ringan, namun pada saat ini seringkali dipakai sebagai kotak pembungkus ${ }^{(1)}$. Styrofoam dijadikan wadah makanan karena murah, mudah didapat, tidak mudah rusak, tidak perlu dibersihkan, dan dapat langsung dibuang ketika sudah tidak digunakan ${ }^{(2)}$.

Hasil penelitian yang dilakukan oleh Lembaga ilmu Pengetahuan Indonesia (LIPI) pada 18 kota utama di Indonesia menunjukkan bahwa sebanyak 270.000 hingga 590.000 ton sampah ditemukan Styrofoam lebih dominan dari sampah jenis lain. Sampah ini masuk ke laut Indonesia selama $2018^{(3)}$.

Penelitian yang dilakukan oleh Teny dkk (2021) mengatakan bahwa Pengetahuan responden tentang penggunaan Styrofoam ini masih tergolong rendah, dimana terdapat 87 
orang atau $73,1 \%$ responden yang masih belum mengetahui tentang bahaya Styrofoam jika digunakan sebagai wadah makanan dalam kehidupan sehari-hari. Sementara itu sikap responden terhadap penolakan jika diberi makanan atau minuman yang menggunakan Styrofoam sebagai kemasannya ada sebanyak $57,1 \%$ atau sebanyak 68 orang yang menolak. Banyaknya responden yang menolak sebenarnya ini menunjukkan sikap yang benar. Namun disisi lain ada sebanyak $42,9 \%$ atau 51 orang responden menjawab menerima jika diberi makanan yang menggunakan bahan Styrofoam sebagai wadah makanan. Bahaya dari penggunaan Styrofoam terhadap kesehatan dan lingkungan sudah banyak diketahui oleh masyarakat. Akan tetapi, masyarakat sepertinya sudah ketagihan dan tidak ada pilihan bahan lain yang memiliki harga murah dan mudah ditemukan $^{(4)}$.

Penelitian yang dilakukan oleh Alhidayati (2021) menjelaskan bahwa, mayoritas responden $65(54,2 \%)$ responden yang menggunakan Styrofoam pada kemasan makanan, $70(58,3 \%)$ responden yang memiliki pengetahuan rendah, $63(52,5 \%)$ responden yang bersikap negatif. Kurangnya informasi yang mereka dapatkan terkait bahaya dari penggunaa Styrofoam, dan juga ada beberapa dari mereka yang senang memesan makanan via gofood. Mereka menilai pemesanan via gofood lebih praktis tanpa harus pergi ke tempat penjual makanan tersebut dan diantara mereka mengatakan bahwa pemesanan makanan via gofood juga banyak yang menggunakan Styrofoam (nasi goreng, mie goreng, ayam geprek, mie ayam, pisang coklat, jamur crispy, bakso bakar, dan lain sebagainya) ${ }^{(5)}$.

Indonesia sendiri masih belum ada peraturan yang melarang penggunaan Styrofoam sebagai wadah makanan. Sebenarnya Bandung sempat diberlakukan larangan penggunaan Styrofoam, namun sepertinya larangan itu tidak diikuti oleh kotakota yang lain di Indonesia. Wali kota Bandung menjelaskan larangan penggunaan Styrofoam didasarkan alasan kesehatan dan lingkungan ${ }^{(4)}$. Menurut asosiasi keamanan makanan Jepang menyampaikan bahwa residu Styrofoam dalam makanan dapat menyebabkan Endocrine Disrupter (EDC), suatu penyakit yang terjadi akibat adanya gangguan pada sistem endokrinologi dan reproduksi manusia akibat bahan karsinogen dalam makanan. Toksisitas yang ditimbulkan memang tidak langsung 
tampak. Sifatnya akumulatif dan dalam jangka panjang baru timbul akibatnya(6). Salah satu dampak dari penggunaan Styrofoam adalah global warming karena senyawa Cloro Fluoro Carbon (CFC) yang dapat menyebabkan efek rumah $\mathrm{kaca}^{(2)}$. Oleh karena itu penulis melakukan Literature Review untuk mengetahui hubungan pengetahuan dan sikap masyarakat terhadap penggunaan Styrofoam sebagai wadah makanan.

\section{METODE}

Metode yang digunakan pada studi literatur ini adalah dengan cara Literatur review. Sumber informasi yang digunakan untuk pencarian referensi artikel literatur topik ini menggunakan Google Scholar, Indonesia Onesearch, dan Science Direct. Istilah pencarian/pembatasan dalam pencarian referensi artikel literatur ini adalah menggunakan kata kunci dan artikel dilakukan dengan menggunakan "Hubungan", "Pengetahuan","Sikap" dan "Styrofoam". Pencarian artikel dilakukan dengan menggunakan database jurnal penelitian secara online. Pemilihan artikel literatur yang akan direview tidak ditetapkan dengan menggunakan kriteria inklusi. 
PRISMA FLOW CHART

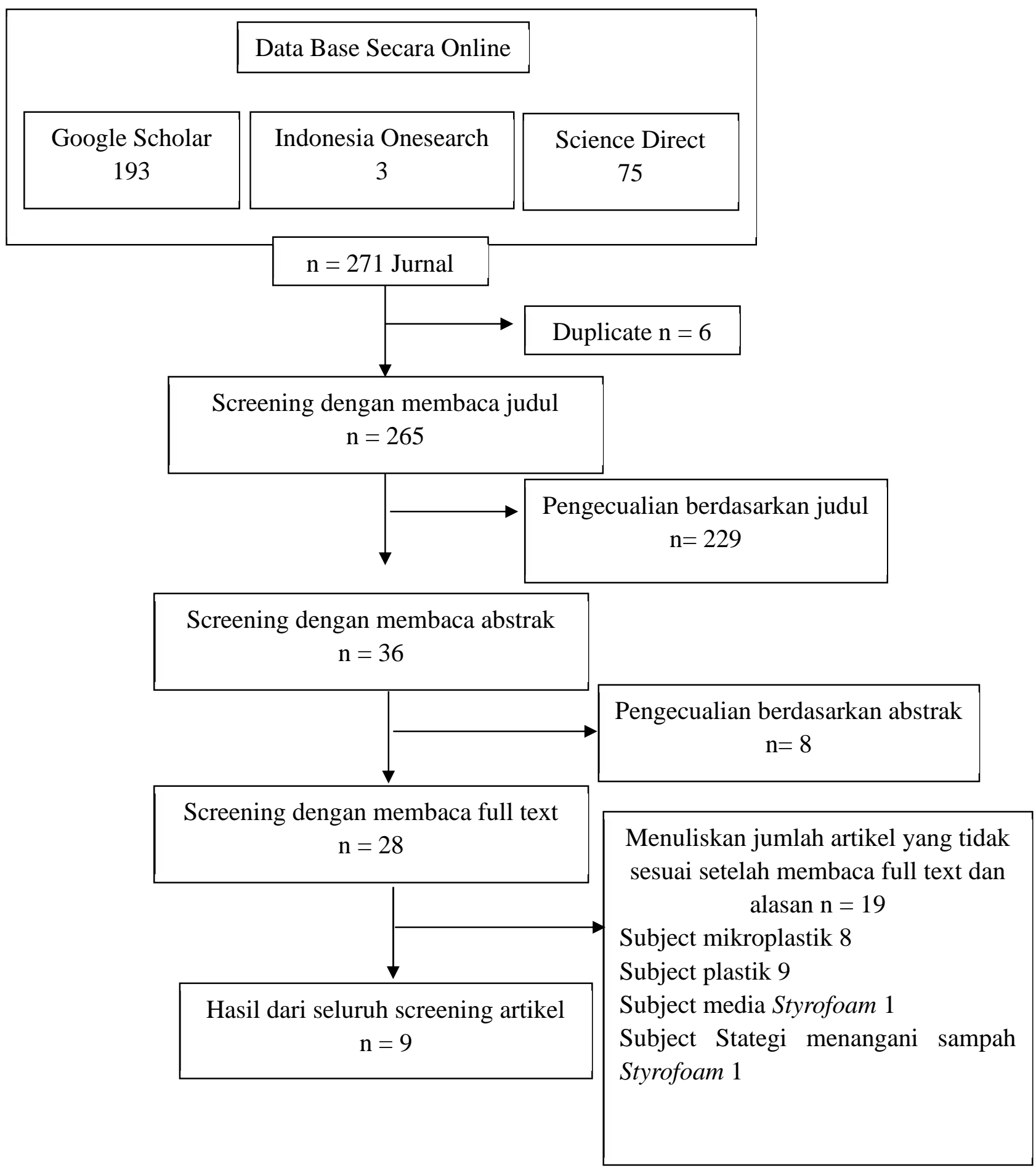




\section{DISKUSI}

1. Sintesis

Aspek pengetahuan merupakan suatu hal yang mutlak diperlukan dalam rangka perubahan pola pikir dan perilaku suatu kelompok masyarakat ${ }^{(6)}$. Faktor yang mempengaruhi pengetahuan yaitu faktor umur, Intelegensi seseorang, lingkungan, sosial budaya, informasi yang diterima, pendidikan dan pengalaman seseorang ${ }^{(7)}$. Pengetahuan masyarakat terhadap penggunaan Styrofoam masih kurang ini dikarenakan minimnya sumber informasi yang diperoleh. Mereka memperoleh informasi hanya berdasarkan dari sesuatu yang mereka lihat dalam kehidupan sehari-hari tanpa melakukan studi literatur yang relevan terhadap informasi yang mereka peroleh. Hal ini sesuai dengan teori yang menyebutkan bahwa sebagian besar pengetahuan manusia diperoleh melalui mata dan telinga (Notoatmojo) $^{(4)}$. Pengetahuan dapat diperoleh dari pengalaman sendiri maupun orang lain ${ }^{(8)}$.

Sikap dipengaruhi oleh bebebapa faktor seperti pengalaman yang dialami akan mempengaruhi, sosial ekonomi yaitu suatu kehidupan bermasyarakat berindikator pendidikan, pekerjaan dan penghasilan sebagai tolak ukur, kebudayaan tempat tinggal mempunyai pengaruh besar terhadap pembentukan sikap, orang lain yang dianggap penting seperti orang tua, media massa yaitu sebagai sumber informasi terbaru, faktor emosi yaitu pernyataan penyaluran dan pengendalian $\operatorname{diri}^{(9)}$. Sikap masyarakat terhadap penggunaan Styorfoam lebih cenderung ke arah sikap negatif ini disebabkan karena masih banyak yang menggunakan Styrofoam sebagai wadah makanan dan beralasan praktis dan amannya makanan bila menggunakan Styrofoam $^{(6)}$. Selain itu juga Styrofoam murah dan mudah didapatkan ${ }^{(10)}$. Masyarakat juga beranggapan kalau makanan yang dikemas dengan Styrofoam aman-aman saja dan tidak menimbulkan bahaya terhadap kesehatan. Karena jaman sekarang banyak kita temukan makananmakanan yang dikemas menggunakan 
wadah Styrofoam yang terlihat bagus dan praktis dan lebih kekinian sehingga masyarakat melihat bahwa Styrofoam kemasan yang aman saat ini ${ }^{(5)}$.

Larangan penggunaan wadah Styrofoam sebelumnya sudah diberlakukan beberapa negara. Amerika Serikat misalnya, larangan penggunaan Styrofoam di berlakukan di Washington DC sejak 1 Januari 2015. Pihak pemerintah telah mengeluarkan undang-undang distrik yang melarang penggunaan Styrofoam untuk makanan cepat saji. Kebijakan ini lalu diikuti oleh Kota Portland, Oregon. Indonesia, Bandung merupakan kota pertama yang memberlakukan larangan penggunaan Styrofoam ${ }^{(11)}$. Larangan penggunaan Styrofoam tertuang pada Peraturan Daerah Kota Bandung Nomor 11 tahun 2005 dan surat edaran kementrian lingkungan hidup dan kehutanan tentang langkah-langkah pengurangan sisa makanan dan wadah/kemasan makanan dan minuman, khususnya dalam hal menghindari penggunaan bahan Styrofoam untuk wadah dan kemasan makanan dan minuman ${ }^{(12)}$.

Menurut salah satu masyarakat, kota Bandung merupakan pemakai Styrofoam terbesar, sehingga Styrofoam merupakan salah satu penyebab banjir di Kota Bandung. Semua pedagang kaki lima mulai dari cilok, cakwe, seblak, siomay, dll menggunakan Styrofoam sebagai wadah kemasan makanan dan minuman. Masyarakat berpendapat bahwa mereka memakai Styrofoam lantaran harga yang murah dan penggunaan yang praktis. Tetapi salah satu masyarakat merasa kecewa dengan adanya larangan penggunaan Styrofoam di kota Bandung, dikarenakan justru Styrofoam ini sangat membantu mereka terhadap kemudahan dan kenyamanan masyarakat, menurutnya yang perlu diubah adalah pola pikir kita sebagai masyarakat untuk tidak membuang sampah Styrofoam sembarangan sehingga tidak menyebabkan efek buruk pada lingkungan ${ }^{(13)}$.

Banyak orang beranggapan bahwa bila sesuatu itu ada di mana-mana dan 
dipakai oleh banyak orang, maka sesuatu tersebut dianggap aman, penggunaan Styrofoam sebagai wadah makanan saat ini semakin meluas, tetapi tidak sedikitpun memunculkan rasa kekhawatiran masyarakat bahwa Styrofoam dapat mengganggu kesehatan $\left(\right.$ Khomsan, 2003) ${ }^{(14)}$. NS melaporkan migrasi Bisfenol A (BPA) dan EDC dari plastik pada suhu yang ekstrim membuat makanan dalam kemasan plastik bisa membahayakan bagi kesehatan manusia ${ }^{(15)}$. Menurut penelitian yang dilakukan oleh Izhar Husain dkk (2015) mengatakan bahwa kemasan makanan sekali pakai mengandung bahan kimia beracun dan sewaktu zat-zat itu bersentuhan dengan makanan atau minuman yang panas, zat kimia beracun yang ada didalam wadah pindah ketubuh manusia melalui makanan dan menyebabkan berbagai penyakit mematikan serta gangguan dalam tubuh manusia seperti kanker ${ }^{(16)}$. Styrofoam sangat berbahaya bagi lingkungan dikarenakan senyawa polystyrene ini tidak dapat diuraikan oleh alam, sehingga akan menumpuk dan mencemari lingkungan yang berdampak turunnya kualitas lingkungan. Salah satu dampak dari penggunaan Styrofoam adalah global warming dikarenakan senyawa Cloro Fluoro Carbon (CFC) yang memberikan dampak efek rumah kaca. CFC bila berada di atmosfer akan menyerap sinar inframerah yang dipantulkan oleh bumi. Peningkatan kadar gas rumah kaca akan meningkatkan efek rumah kaca yang dapat menyebabkan terjadinya pemanasan global $^{(17)}$.

\section{Keterbatasan}

Keterbatasan Literatur Review ini yaitu terbatasnya jumlah artikel mengenai topik yang di review dikarenakan lebih banyak jurnal yang membahas mengenai pemanfaatan limbah styrofoam.

\section{KESIMPULAN}

Berdasarkan hasil Literatur Review ini dapat disimpulkan bahwa pengetahuan dan sikap berhubungan dengan penggunaan Styrofoam sebagai wadah makanan, faktor 
yang dapat mempengaruhi pengetahuan seseorang yaitu dari faktor umur, Intelegensi seseorang, lingkungan, sosial budaya, informasi yang diterima, pendidikan dan pengalaman seseorang. Sedangkan faktor yang mempengaruhi sikap seseorang yaitu pengalaman yang dialami, sosial ekonomi, pekerjaan dan penghasilan, kebudayaan, orang lain yang dianggap penting seperti orang tua, media massa, faktor emosi yaitu pernyataan penyaluran dan pengendalian diri. Styrofoam masih sering digunakan oleh masyarakat dikarena harganya yang murah, praktis dan mudah didapat, tanpa disadari bahwa penggunaan Styrofoam yang terus menerus akan menyebabkan dampak terhadap kesehatan maupun lingkungan.

\section{SARAN}

Perlu dilakukan penyuluhan kesehatan terkait dengan Styrofoam sebagai wadah makanan. Dengan memanfaatkan media sosial sebagai tempat untuk memberikan informasi mengenai bahaya penggunaan Styrofoam.

\section{DAFTAR PUSTAKA}

1. Munawaroh I, Suryani D, Masyarakat Fakultas Kesehatan Masyarakat Universitas Ahmad Dahlan Jl Profdrsoepomo K. FaktorFaktor Yang Mempengaruhi Penggunaan Wadah Styrofoam Sebagai Kemasan Makanan Pada Penjual Makanan Jajanan Di Kota. 2016 [Cited 2021 Nov 10]; Available From: Http://Repository.Unmuhpnk.Ac.Id/Id/Eprint/ 8

2. Pengetahuan A, Sikap D, Tentang $M$, Styrofoam P, Dwi Untari A, Astuti Y. Analisis Pengetahuan Dan Sikap Mahasiswa Tentang Penggunaan Styrofoam. Journal.Unilak.Ac.Id [Internet]. 2020 [Cited 2021 Nov 10];7(2). Available From: Http://Journal.Unilak.Ac.Id/Index.Php/BL/Arti cle/View/5301

3. Jamil AI. 590.000 Ton Sampah Masuk Ke Laut Indonesia Per Tahun, Styrofoam Mendominasi [Internet]. Inews.Id. 2019. Available From: Https://Www-InewsId.Cdn.Ampproject/Org/V/S/Www.Inews.Id/A mp/News/Nasional/590000-Ton-SampahMasuk-Ke-Laut-Indonesia-Per-TahunStyrofoamMendominasi?Amp_Gsa=1\&Amp_Js_V=A6 $\& U s q p=M q 331$ aqkkafqarabiiacaw\%3D\%3D\# Amp_Tf=Dari \%251\%24s\&Aoh=1639992759 8384\&Referrer=Https\%3A\%2F\%2Fwww.Goo gle.Com\&Ampshare $=\mathrm{Https} \% 3 \mathrm{~A} \% 2 \mathrm{~F} \% 2 \mathrm{Fww}$ w.Inews.Id\%2Fnews\%2Fnasional\%2F590000Ton-Sampah-Masuk-Ke-Laut-Indonesia-PerTahun-Styrofoam-Mendominasi

4. Kurniasari T, Subhan W, Kalimantan No J, Jember Atenykurniasari S. Gambaran Pengetahuan Dan Sikap Siswa Sman Balung Terhadap Bahaya Styrofoam Sebagai Wadah Makanan. 114797221 [Internet]. 2021 [Cited 
2021 Nov 10];6(1):2355-892. Available From: Http://114.7.97.221/Index.Php/Kesehatan_Ma syarakat/Article/View/1675

5. Maharani R. Styrofoam Pada Kemasan Makanan Di Stikes Hang Tuah Kota Pekanbaru Tahun 2020. 2021;2(1):52-63.

6. Sabilu Y, Halik NH, Yasnani Y. Perilaku Penggunaan Styrofoam Sebagai Kemasan Makanan Pada Rumah Makan Di Kota Kendari. Prev J. 2020;4(2):82-8.

7. Munawaroh I, Suryani D, Masyarakat Fakultas Kesehatan Masyarakat Universitas Ahmad Dahlan Jl Profdrsoepomo K. Hubungan Pengetahuan Dan Sikap Penjual Makanan Online Terhadap Penggunaan Wadah Styrofoam Di Wonomulyo. J-KESMAS J Kesehat Masy [Internet]. 2019 [Cited 2021 Nov 10];5(1). Available From: Https://Www.Neliti.Com/Publications/283675/ Hubungan-Pengetahuan-Dan-Sikap-PenjualMakanan-Online-Terhadap-Penggunaan-

Wadah

8. Jumadewi A, Staf , Prodi P, Keperawatan D, Aceh K, Alamat T , Et Al. Gambaran Perilaku Mahasiswa Tentang Bahaya Penggunaan Plastik Sebagai Wadah Makanan Dan Minuman Prodi DIII Keperawatan. Ojs.Serambimekkah.Ac.Id [Internet]. Available From:

Http://Www.Ojs.Serambimekkah.Ac.Id/Makm a/Article/View/1306/1053

9. Utami AM Yuni, Listina F, Novariana N. Faktor-Faktor Yang Berhubungan Dengan Perilaku Mahasiswa Dalam Penggunaan Plastik Dan Styrofoam Untuk Pembungkus Makanan Di Fakultas Kesehatan Universitas Mitra Indonesia Tahun 2020. J Formil (Forum Ilmiah) Kesmas Respati. 2020;
10. Swamilaksita P, Sitoayu L, Sciences NSKL, 2018 Undefined. Knowledge, Attitude, And Behavior Of Housewives In Using Styrofoam Packaging In West Jakarta. Knepublishing.Com [Internet]. [Cited 2021 Nov 11];2018. Available From: Https://Www.Knepublishing.Com/Index.Php/ Kne-Life/Article/View/2592

11. Wulan RT. Pertama Di Indonesia, Kota Bandung Larang Penggunaan Styrofoam [Internet]. Www.Voaindonesia.Com. 2016 [Cited 2021 Nov 26]. Available From: Https://Www-Voaindonesia-

Com.Cdn.Ampproject.Org/V/S/Www.Voaindo nesia.Com/Amp/Pertaa-Di-Indonesia-Kota-

Bandung-Larang-Penggunaan-

Styrofoam/3584677.Html?Amp_Gsa=1\&Amp _Js_V=A6\&Usqp=Mq331aqkkafqarabiiacaw \%3D\%3D\#Amp_Tf=Dari \%251\%24s\&Aoh=1 6378255135024\&Referrer

12. Surat Edaran Mengenai Pelarangan Membuang Sampah Sembarangan Dan Penggunaan Kemasan Berbahan Polistirena (PS) Foam Atau Styrofoam.

13. Ernawan R. Merubah Perilaku Masyarakat Pengguna Styrofoam [Internet]. Standarisasi.Menlhk.Go.Id. 2021 [Cited 2021 Nov 26]. Available From: Https://Standarisasi.Menlhk.Go.Id/Index.Php/ 2017/01/23/Merubah-Perilaku-MasyarakatPengguna-Styrofoam/

14. Munawaroh I, Suryani D, Masyarakat Fakultas Kesehatan Masyarakat Universitas Ahmad Dahlan Jl Profdrsoepomo K. Hubungan Pengetahuan Dan Sikap Penjamah Makanan Kapal Penumpang Terhadap Penggunaan Styrofoam Sebagai Wadah Makanan Di Pelabuhan. J-KESMAS J Kesehat Masy [Internet]. 2016 [Cited 2021 Nov 10];2(2). 
Available From:

Https://Core.Ac.Uk/Download/Pdf/228641601

.Pdf

15. Preez M Du, Der Merwe D Van, Journal Of ... LW-I, Undefined 2021, Merwe D Van Der, ... LW-I Journal Of, Et Al. Assessing Knowledge And Use Practices Of Plastic Food Packaging Among Young Adults In South Africa: Concerns About Chemicals And Health. Mdpi.Com [Internet]. 2021 [Cited 2021 Nov
11];18:10576. Available From: Https://Www.Mdpi.Com/16604601/18/20/10576

16. Hanga AH. Disposable Plastic Food Container And Its Impacts On Health. J Energy Environ Sci. 2015;130(12):618-23.

17. Wirahadi M. Elemen Interior Berbahan Baku Pengolahan Sampah Styrofoam Dan Sampah Kulit Jeruk. J Intra. 2017;5(2):144-53. 